DOI: $10.1515 /$ rpp-2017-0017

Doctor of Pedagogical Sciences, Associate Professor, NATALIA PAZYURA

National Aviation University

Address: 1 Kosmonavt Komarov Ave, Kyiv, 03058, Ukraine

E-mail:npazyura@ukr.net

\title{
FOREIGN SCHOLARS' THEORETICAL APPROACHES TO USING SOCIAL NETWORKS AS EDUCATIONAL STRATEGIES
}

\begin{abstract}
Modern trends in development of information and communication technologies change many aspects in the process of education: from the role of participants to the forms and methods of knowledge delivery. ICTs make it possible to develop students' creative potential. The emergence of online social groups was an important event in the sphere of communication but with time they began to be used by both teachers and students not only for communication, but also to achieve learning goals. Without any doubt, skillful use of social networks allows teachers to communicate with students at modern technological level, make classes more attractive and effective. An efficient teacher can prove that social networks are not only means of entertainment and communication with friends but are a working tool. The main aim of foreign language teaching is students' communicative activity or practical use of a target language. The teacher is to activate every student's activity in the process of learning, make situations for their creativity. The main objective of foreign language teaching is to educate an individual, who is able to communicate, continue education, including selfeducation. Different theories lay the basis for the study of social networks' influence on different aspects of human activity and, particularly, education. The main theories are sociocultural theory and social constructivist theory. According to sociocultural theory, man is an integral part of the world they live in, so students are not independent in their activities. Social constructivist theory recognizes that students act in a certain environment, which under certain conditions enlarges their practical knowledge. These theories are focused on the effect of social interaction, language and culture in the learning process. Thus, theoretical basis proves positive effect of social networks, namely, they enhance substantial interaction in the educational environment of social groups as well as are directed at strengthening the values, exchange of opinions and experience with a practical orientation.
\end{abstract}

Keywords: social networks, foreign language teaching, communicative skills, theoretical basis, students' motivation, ICTs, education.

\section{INTRODUCTION}

Nowadays, the modern educational system is functioning under the conditions of constant changes due to the appearance of new information and communication technologies, rapid spread of knowledge, diversification of knowledge delivery. In the era of globalization, information and communication technologies act as an activator of the learning process, increase the effectiveness of educational managers. In modern knowledge-based society there is the need for knowledge distribution by electronic means of communication as an extremely important way of providing information that should be conducted in accordance with national economic, social and cultural demands. ICTs development resulted in the emergence of online social groups, which are used by both teachers and students not only 
for communication, but also to achieve learning goals. The promotion of websites aimed at social interaction and communication has led to their integration into the everyday life of young people.

Social media is becoming more and more popular due to the growing number of users. They do not only change the traditional teaching model, but also contribute to the efficiency of the education process by providing new opportunities for students in building their own learning trajectory, access to information resources, educational services and due to their focus on cooperation create social groups encouraging communication with native speakers.

In this context, an important task for contemporary teachers is to improve their competency in the use of new technologies outside the classroom. Also, it is important to remember that many students are now more "enlightened" in this sphere than their teachers.

\section{THE AIM OF THE STUDY}

The aim of the article is to characterize the peculiarities of foreign language teaching with the help of social networks, analyze theoretical approaches to teaching with modern means of communication, reveal the effectiveness of the process.

\section{THEORETICAL FRAMEWORK AND RESEARCH METHODS}

Social network is a method of communication that is rapidly replacing the traditional forms such as letters, faxes, email and even phone calls. Today social networks are used for advertising, voting, promotion of products, as a platform for the latest news and social interaction. The problem of bringing social networks in the education process is quite new. However, some scholars have made attempts to examine the role of Facebook in foreign language teaching (Balcikanli, 2015; Hamada, 2013; Huang, Lin \& Villarreal, (2014). They have recognized that determining its effectiveness is a question that needs more research. In addition to them, the popularity of social networks, especially Facebook, has been studied by P. Ventura \& E. Martín-Monje (2016). The effect of using Facebook to assist English for specific purposes has been considered by R. Ch. Shih (2013). The use of Facebook in educational activities and its role in increasing students' motivation has been discussed by M. Maniam, N. S. Ping (2015), J. Mazer, R. Murphy \& C. Simonds (2007).

For our research we have used general scientific methods, namely, analysis, synthesis and generalization of the received information on different theoretical approaches to using social networks in education.

\section{RESULTS}

Various aspects and influence of social networks and other virtual means of communication became the object of researches. Training via Skype, especially for development of English communication skills is quite new. Professor G. Godwin-Jones from Virginia Commonwealth University studied the use of Skype for online learning. Also, A. Elia revealed its influence on language learning. C. Beltrán conducted a research on the influence of Skype chat on communication skills in a group of students with English proficiency level of A2. The scholar concluded that communication in Skype increases students' motivation and is an excellent opportunity to improve teachers' activities, too (Correa, 2015).

According to English scholars M. Pawlak, E. Waniek-Klimczak, J. Majer, mastering the skills of foreign language communication is a difficult task as the acquisition involves the mastery of different linguistic subsystems to the point where they are used automatically in spontaneous communication. Therefore, the main function of a foreign language teacher is to create special conditions for the development of communication skills, abilities to interact in different linguistic and social circumstances, use accurately but spontaneously these language subsystems. To A. Vaseki's opinion, such a task is extremely important in the globalized world where today's youth wants to communicate with 
representatives of other countries, ethnic groups, races and the like, because the ability to speak a foreign language increases their confidence and self-esteem (Ping \& Maniam, 2015).

The study of social networks' influence on different aspects of human activity and education, in particular, should be carried out with reference to theoretical foundations. Thus, sociocultural theory is valuable for our study, which indicates that man is an integral part of the world they live in, so students are not independent in their activities, i.e., the student does not study in isolation, but in interaction with others. Therefore, teachers should offer more chances to learn interactively and in cooperation. H. Pi believes that the messages that are exchanged in social networks develop students' critical thinking and literacy skills by using language in a real context. D. Marmc, D. Mccormick expressed the assurance that the sociocultural theory was the basis for the development of learning strategies in foreign language learning. They found out that students' participation in the communication with the members of community was characterized by their ability to grow, reflect on and improve their language strategies (Ping \& Maniam, 2015).

Recently much attention has been paid to social perspectives of education. A significant number of researches on online courses have been conducted under the influence of the constructivist theory and the theory of social learning. During the 1990s, constructivism had a strong influence on education, especially in the question of learning technologies. The social constructivist theory recognizes that students act in a certain environment; in such a way there is reflection, abstraction and increasing practical knowledge. On the other hand, it is focused on the effect of social interaction, language and culture in the learning process. Some scholars believe that according to the principles of the constructivist theory substantial interaction in the educational environment of social groups is directed at strengthening the values, exchange of opinions and experience with a practical orientation. Some of them suggest that the paradigm of social constructivism is focused on student-centered learning so that students can share their knowledge, skills, experience and ideas with others. Also, students are encouraged to take part in active dialogues with groupmates and teachers, cooperate with each other, create knowledge and discover some principles for themselves. British scholars Q. Wang, H. L. Woo, C. L. Quek, Y. Yang \& M. Liu (2012) note that learning should be conducted through web-technologies supported by such theories emphasizing the creation of specific learning environment where students can have an access to knowledge and share information and resources with others.

Therefore, learning by using Internet technologies can stimulate and support the learning process and provide positive results. Once students gain the opportunity to participate in group discussion on Facebook, they use the language modified to their proficiency level and gradually acquire communication skills in a foreign language. At this stage, experienced students help groupmates in the discussion and, finally, students with less knowledge and skills feeling the support can initiate a discussion with others (Ping \& Maniam, 2015).

Our analysis suggests that a modern process of language learning outside the classroom is mostly conducted in an informal way. Informal learning with the help of ICTs is an alternative environment for language practice and, therefore, it should be studied by scholars for further practical realization. Informal learning is considered as a link or bridge between social media and academic content learning. It offers more options for students, provides deeper study of the learning content. In this context, the learning process occurring outside the classroom with the help of ICTs and being focused on discussions on the meanings of words and the creation of knowledge, social and personal interaction and forming of relations between the objects of study is extremely important. The scholar from 
Monash University N. Selwyn argues that computers and other aspects of ICTs enable young people to take part in a wide range of activities, although they do not occur in a traditional educational environment (Shih, 2013).

Taking into account that computer-mediated communication (CMC) is now gaining popularity and recognition among academicians and practitioners as an effective means of acquiring communication skills in a foreign language, we believe it necessary to consider various scholars' views on the essence and features of realization in the education process for students of different specialties in more detail. C. Lengel, A. Thurlow, L. Tomic determine the $\mathrm{CMC}$ as any communication between people that occurs through computer technology. In other words, it is the integration of computer technology in everyday life, which actualizes the study of how human behaviour is maintained or altered by exchanging information through machines (Correa, 2015).

American scholars from University of California R. Kern and M. Warschauer believe that an access to social networks helps students to communicate with other learners or native speakers. In addition, M. Levi and G. Stockwell are sure that CMC tools provide teachers with the opportunity to monitor learning outcomes easily and with minimal interference in the learning process (Correa, 2015).

In this context, Skype conference calls are a valuable tool for communication and interaction among the participants of the education process. Skype not only ensures oral communication and enhances social relationships both with fellow students and other members of the communication, but also increases the effectiveness of extra-curricular activities. Some experiments have been conducted to test the hypothesis that Skype conference calls may improve social interaction skills of students with A1 language proficiency level outside the classroom. J. Nash and J. Calonico define social interaction as the process of communication and mutual influence that involves contact between two or more individuals. Scholars in University of Albany K. Fitch and R. Sanders believe it to be a diversified and multidisciplinary convergence of interests, which include discourse analysis, ethnography and social psychology (Correa, 2015).

In 2003, S. Boyd first suggested that social networks were software applications that support the development of social ties between individuals within certain groups. In 2006, Australian scholar from University of Technology, Sydney, A. Bartlett-Bragg indicated that social networks were a set of applications which promote communication and personal interaction within a group and spread the scope of cooperation, social ties, promote the exchange of information in the webspace. As one can see, the scholars' definitions draw attention to the fact that social networks are based on the interaction of individuals with each other in a common space for cooperation and exchange of information. D. Boyd defines social networking sites as web services that allow a person to create a public profile with a specific system of restrictions to determine the list of users with whom he or she comes into contact (Balcikanli, 2015).

Turkish researchers H. Ajjan and R. Harsthone identified the benefits of social networks in an educational context: they activate students' learning process, their motivation and the interaction between the student and the teacher aimed at developing students' writing skills (Balcikanli, 2015).

Some researchers (P. Norris, P. Resnick) believe that social networks are very influential in the development of relationships between participants and thus support a wide range of relationships (Norris, 2002). J. Mazer, R. Murphy \& C. Simonds (2007) consider that teachers using social networks can motivate students and create a more comfortable 
climate in the classroom. H. Ajjan \& R. Harsthone (2008) also found out that such social networking tools enhance the learning motivation, interaction between students and teachers, the integration of different applications in the education process.

However, there is certain criticism of social networks. So, C. Dainty finds that the negative effect of social networking and especially Facebook is manifested in the absence of empathy, unstable sense of identification among children, a short period of concentration. But, others believe it is the intelligent use of modern technology in the classroom (Balcikanli, 2015).

Many scholars called Facebook the social glue. It is increasingly seen as an educational tool due to its beneficial qualities (feedback, interaction, social activity). From the point of view of social impact, Facebook accelerates the learning process and makes it less routine. Students in groups talk about their lives, share thoughts, discuss interests, training, find out questions about homework, exams, collaborative projects. From the point of view of efficiency in the learning process, Facebook enhances the "student teacher teacher-student" interaction of in web communication. Thus, Facebook is of interest to researchers in three aspects: as a mass social phenomenon; as a unique ability to monitor the private behaviour of certain categories of people; as the model of information exchange among young people (Balcikanli, 2015).

S. Warnock states that the first reason to teach writing online is that the environment can only be contextual. The students are taught in a rich, managed learning environment in which they express their thoughts to a diversified audience in a written form. Electronic means of communication allow students to communicate in writing with the teacher and other students and this presents new educational opportunities for all participants of this process. In addition, this is a unique opportunity to use online courses to make teachers and students interact outside of the training content. These e-groups are the basis for the further social and professional connections that make up the value of education (Ping \& Maniam, 2015).

M. Melor indicates that social interactions have a positive impact on the development of lifelong education. Social interaction helps develop research skills, teaches to evaluate the obtained results and communicate with peers. The education process usually takes place in the classroom in the form of personal communication between its participants, but now it can be implemented with the help of social networking technologies including the discussion between participants and evaluation of group-mates' answers (Ping \& Maniam, 2015).

According to certain researches, Facebook influences students' motivation and strengthens the practical component of the education process. It increases the level of interaction on web-based resources, helps teachers develop relationships with students outside the classroom, discuss problems that are interesting for students. The study of Facebook as a useful learning environment for English learning indicates that such factors as students' self-confidence, motivation have been greatly improved. Students add that the use of Facebook significantly influences their confidence, makes them feel free in the use of writing skills (Ventura \& Martín-Monje, 2016).

A. Selami points out that discussions in social networks create the context in which the teacher talks less when the students talks more. The learning process becomes more student-centered. Group discussions allow the students to brainstorm before they write a message as Facebook is the most commonly used application in which the sender can edit the message many times before sending it (Ping \& Maniam, 2015).

The results show that students tend to discuss issues important to them in social networks, in groups on Facebook rather than in the classroom. In case of low self-esteem, 
they cannot share opinions in class and offer their opinions for discussion. The discussion group in social networks provides a place where ideas are posted for all, open to criticism and praise. Students develop skills of organization, synthesis and analysis of the views independently and together with classmates. This creates the conditions for meaningful learning in which group members can generate ideas. In such a way, students gain confidence in written responses because they are supported and receive positive feedback. During the exchange of thoughts, messages and comments on Facebook, students develop confidence, so Facebook groups help to support, brainstorm and improve writing skills. All studies show students' positive attitude to group discussions on Facebook. However, it is very important to direct the students' attention to the aspects of learning in order to represent educational goals and work at achieving them (Hamada, 2013).

In this context, we should draw attention to the fact that it is important for teachers to improve their competence by using new technologies and encourage students to use these technologies independently and outside the classroom.

\section{CONCLUSIONS}

Thus, social media is becoming more and more popular due to the growing number of users. The growing popularity of websites aimed at social communication has led to their integration into the everyday life of young people. But now, with the rapid development of information and communication technologies, they are not only a means of communication, but also change the traditional teaching model and contribute to improving the efficiency of the education process. The strong influence of social networks on human activity has made educators reflect on the use of social networks in the educational context. Social networks have a positive effect on encouraging students to practice oral language as it facilitates discussions and enhances the course content in a variety of modern and attractive methods. The results of this experiment allow us to conclude that social networks and especially Facebook can be a powerful tool to enhance online interaction and improve foreign language communication skills. Social media offer new opportunities for students to manage their own learning and more active methods of work in collaboration with teachers, providing access to information resources and services.

Further researches should be conducted in the field of the enhancement of this positive impact with a more full account of the students' individual needs consolidating their involvement in such new types of online courses.

\section{REFERENCES}

1. Ajjan, H., \& Harsthone, R. (2008). Investigating faculty decisions to adopt web 2.0 technologies: theory and empirical tests. Internet and higher education, 11 (2), 71-80.

2. Balcikanli, C. (2015). Prospective English language teachers' experiences on Facebook: adoption, use and educational use in Turkish context. International journal of education and development using information and communication Technology (IJEDICT), 11 (3), 82-99.

3. Correa, R. Y. (2015). Skype ${ }^{\mathrm{TM}}$ conference calls: a way to promote speaking skills in the teaching and learning of English. PROFILE issues in teachers' professional development, 17 (1), 143-156.

4. Hamada, M. (2013). A Facebook project for Japanese university students (2): does it really enhance student interaction, learner autonomy, and English abilities? In L. Bradley \& S. Thouesny (Eds.), 20 years of EUROCALL: learning from the past, looking to the future. Proceedings of the 2013 EUROCALL conference, Evora, Portugal (pp. 98-105). 
5. Huang, C. K., Lin, C. Y., \& Villarreal, D. S. (2014). Contextual language learning: educational potential and use of social networking technology in higher education. In S. Jager, L. Bradley, E. J. Meima, \& S. Thouësny (Eds.), CALL design: principles and practice. Proceedings of the 2014 EUROCALL conference, Groningen, The Netherlands, (pp. 158-164).

6. Mazer, J. P., Murphy, R. E., \& Simonds, C. J. (2007). I'll see you on "Facebook": the effects of computer-mediated teacher self-disclosure on student motivation, affective learning, and classroom climate. Communication education, 56 (1), 1-17.

7. Norris, P. (2002). The bridging and bonding role of online communities. Press/politics, 7 (3), 3-13.

8. Ping, Ng S., \& Maniam, M. (2015). The effectiveness of Facebook group discussions on writing performance: a study in matriculation college department of education (TESL). Malaysia international journal of evaluation and research in education (IJERE), 4 (1), 30-37.

9. Shih, R. Ch. (2013). Effect of using Facebook to assist English for business communication course instruction. Tojet: the Turkish online journal of educational technology, 12 (1), 52-59.

10. Ventura, P., \& Martín-Monje, E. (2016). Learning specialized vocabulary through Facebook in a massive open online course. In A. Pareja-Lora, C. Calle-Martínez, P. Rodríguez-Arancón (Eds), New perspectives on teaching and working with languages in the digital era (pp. 117-128). Dublin: Research-publishing.net.

11. Wang, Q., Woo, H. L., Quek, C. L., Yang, Y., \& Liu, M. (2012). Using the Facebook group as a learning management system: an exploratory study. British journal of educational technology, 43 (3), 428-438. 